\title{
EVALUATION OF PROMISING FABA BEAN (Vicia faba L.) GENOTYPES FOR AGRONOMIC AND SEED TECHNOLOGY CHARACTERS IN NORTH EGYPT \\ El-Emam, A. A. M. ${ }^{1}$ and E. M. Rabie ${ }^{2}$ \\ 1- Seed Tech. Res. Sec. Field Crops Res. Institute, A.R.C. \\ 2- Legumes Crops Res.Sec. Field Crops Res. Institute, A. R. C.
}

\begin{abstract}
Field and laboratory experiments were conducted at Gemmeiza Agric. Res. Station and Mansoura Seed Tech. Unit, Agricultural Research Center during $2011 / 2012$ and 2012/2013 seasons to evaluate promising ten faba bean genotypes with three commercial cultivars; Giza 843, Misr 1 and Improved Giza 3. The main results cleared, Genotype 9 was the earliest in flowering and maturity dates. Genotypes 1,3,5 and 8 surpassed in number of pods/plant and number of seeds/plant. Genotypes 4,1,8 and 3 surpassed the other genotypes in 100-seed weight, seed weight/plant, germination percentage, seedlings vigor traits, meanwhile, recorded the lowest values for mean germination time and electrical conductivity compared with the three local commercial cultivars. There were positively and highly significant correlations between seed weight/plant and each of number of seed/plant, germination percentage, seedling length, seedling vigor index and germination rate, while, negatively and highly significant correlations between seed weight/plant both of electrical conductivity and mean germination time. Generally, under North Egypt conditions, we can sowing promising faba bean genotypes $4,1,8$ and 3 (G.461 $\times G_{.402}$, G. ${ }_{461} \times$ Nubaria $1 \mathrm{H}_{.8} \times \mathrm{G}_{.461}$ and $\mathrm{G}_{.716} \times \mathrm{G}_{.402}$ ) to obtain high yield/plant and good seed quality as well as using them in breeding program.
\end{abstract}

\section{INTRODUCTION}

Faba bean (Vicia faba L.), is known to be an efficient nitrogen fixer about $80 \%$ of nitrogen from the atmosphere and that means $300 \mathrm{~kg} / \mathrm{h} /$ year for a yield of $5000 \mathrm{~kg}$ ha-1 (Huber et. al., 1987). Large-seeded faba bean seed is usually used as food, while medium-sized seed is used as food and feed, with small-sized grain mainly used as feed (Redden et al., 2007). However, in spite of its great potential for being an important protein source in many countries, its area of cultivation has been decreasing over the years (Torres et al., 2010). This reduction is mainly attributed to the unstable yielding ability of faba bean. In Egypt, faba bean is one of the main pulse crops grown for seed and the major problem of faba bean crop is the low and unstable yield from season to another. Alghamdi, (2007) studied the genetic behavior of six faba bean genotypes grown in central region of Saudi Arabia, he demonstrated that genotype Giza 402 showed the tallest plants, highest number of pods/plant, seed weight per plant and seed yield (t/ha) and significant positive correlations were detected between seed yield (t/ha) and each of number of pods/plant, number of seeds/plant and seed weight/plant, while, negative and significant correlations were observed between seed yield ( $\mathrm{t} / \mathrm{ha}$ ) and each of flowering time, maturity date, number of branches per plant and 100-seed weight. Wally et. al., (2010), performance evaluation of five breeding lines of faba bean, they reported that Assiut 125 was 
significantly better than all other lines for total dry seed yield in tons/fed, while, Assiut 104/2 and Romy 3 gave the lowest yield in both seasons. In addition, Assiut 125 was significantly better than all other lines in number of dry pods/plant and dry seed weight/plant. Haridy and Amein (2011), studied some agronomic traits in five faba bean genotypes, they showed that Assiut 44 was the best combiner for number of pods/plant and weight of dry seeds/plant. Assiut $102 / 3$ was the best combiner for days to $50 \%$ flowering and number of primary branches/plant. The genotype Assiut 39 was the best combiner for plant height and number of seeds/pod. Cecilia et. al., (2013), found that pod yield differed among genotypes; 'Verde Bonita' and 'Retaca' genotypes had the highest pod yield (8\%) higher than 'Alarga'. 'Retaca' had a higher pod number $(26 \%$ and $41 \%)$ more than 'Verde Bonita' and 'Alarga', respectively, however, pod weight was the lowest in 'Retaca' as compared with the other two genotypes and pod number was the highest in this genotype.

Seed vigor is an important component of seed quality and satisfactory levels are necessary in addition to traditional quality criteria of moisture, purity, germination and seed health to obtain optimum plant stand and high production of crops. Vigor testing is important because it often gives a better prediction of field performance and is a more sensitive indicator of seed quality than the standard germination test (Younis, et. al., (1990). Since a single test does not necessarily measure all aspects of seed vigor, several tests have been suggested (Hampton and Coolbear, 1990). EL-Emery (1997). found that genotypes differed in germination, seed and seedling vigor traits. Krystyna et. al. (2000), tested thirty-nine strains and cultivars of bean in the field and laboratory over $3 \mathrm{yr}$, they found that standard germination was above $80 \%$ and conductivity ranged from 7 to $45 \mu \mathrm{sm}^{-1} \mathrm{~g}^{-1}$. Olasoji, et. al., (2011), recorded that a wide genetic variation was observed among the cultivars in seed quality traits such as hundred seed weight, germination percentage and germination after ageing as well as bulk conductivity readings. Erkut, (2007), investigate the relationships among electrical conductivity of seed steep water in 15 faba bean (Vicia faba L.) cultivar/ populations, he found that Faba bean cultivar/populations were differed for EC values at both 24th $\mathrm{h}$. EC readings varied from $7.9 \mu \mathrm{S} \mathrm{cm}-1 \mathrm{~g}-1$ in Lara cultivar to $12.1 \mu \mathrm{S} \mathrm{cm}-1 \mathrm{~g}-1$ in Merzifon cultivar at 24th h. Ghassemi and Hosseinzadeh (2009) studied the changes in seed vigour of three faba bean (Vicia faba L.) cultivars Aquodolce, Barakat and Zohreh during development and maturity, they indicated that maximum seed weight, germination rate and minimum electrical conductivity (EC) were significantly affected by cultivar, but the effect of cultivar on maximum germination percentage was not significant. Cultivar Barakat had the highest seed weight and electrical conductivity, compared with other cultivars, in contrast, Zohreh had the smallest seeds with the lowest solute leakage and the highest germination rate.

Seed viability and vigor directly affect the performance of seeds planted to regenerate the crop. The objective of this study was to evaluate ten promising faba bean genotypes for agronomic and seed quality traits comparing with three commercial cultivars. 


\section{MATERIALS AND METHODS}

Field and Laboratory experiments were conducted at Gemmeiza Agricultural Research Station, Gharbia Governorate and Laboratory of Seed Technology Research Unit El Mansoura, ARC, Egypt, during 2011/2012 and 2012/2013 seasons to study the performance of thirteen promising faba bean genotypes Table (1) for yield and its components as well as seed quality characters.

Table (1) Pedigree of origin studied faba bean genotypes.

\begin{tabular}{|c|c|}
\hline Genotypes & Pedigree \\
\hline G. 1 & Giza 461 x Nubaria 1 \\
\hline G. 2 & Treble Weight $x$ Nubaria 1 \\
\hline G. 3 & Giza 716 x Giza 402 \\
\hline G. 4 & Giza 461 x Giza 402 \\
\hline G. 5 & Nubaria 1 x Giza 2 \\
\hline G. 6 & Giza 429 x Giza 2 \\
\hline G. 7 & Giza 429 x Giza 40 \\
\hline G. 8 & Hybrid 8 x Giza 461 \\
\hline G. 9 & Hybrid $10 \times$ Giza 461 \\
\hline G. 10 & (Treble Weight X G. 461) x Misr ${ }_{1}$ \\
\hline Giza 843 & L. $461 / 845 / 83 \times$ L. $561 / 207 \mathrm{~b} / 85$ \\
\hline Misr 1 & G. $3 \times 123 \mathrm{~A} / 45 / 76$ \\
\hline Improved Giza 3 & Selected from Giza 3 (Giza 1 x Introduction 29) \\
\hline
\end{tabular}

The field experiment arranged in randomized complete block design with three replications. The texture of experimental soil was salty clay loam. The soil was ploughed and calcium super phosphate $\left(15 \% p_{2} 0_{5}\right)$ was incorporated into the soil at a rate of $150 \mathrm{Kg} /$ feddan before sowing. Sowing date was $15^{\text {th }}$ November in the first season, while it was $25^{\text {th }}$ November in the second season. Each plot consisted of five ridges, $60 \mathrm{~cm}$ a part and $4 \mathrm{~m}$ long. Seeds were inoculated and hand planted. Hand hoeing was practiced twice to control weeds. All the agronomic practices were conducted as recommended. Data of plant height $(\mathrm{cm})$, number of branches/ plant, flowering and maturity time, number of pods/plant, number of seed/ plant, 100 -seed weight (gm) and seed weight/ plant (gm) were estimated. Seeds of harvested genotypes were undergo to various laboratory testes for evaluating seed quality traits after drying and cleaning.

Standard germination test: was done according to the method outlined in the rules for seed testing (ISTA, 1999). Four replicates of 50 seeds were planted in boxes of $(40 \times 20 \times 20 \mathrm{~cm})$ dimension and contained sterilized sandy soil. The boxes were then watered and kept at $20 \pm 1^{\circ} \mathrm{c}$ in the germination chamber for 14 days. Normal seedlings, abnormal seedlings and ungerminated seed were counted. Germination percentage was defined as the number of normal seedlings after 14 days.

Germination percentage $=$
Number of normal seedlings $\times 100$ Number of seeds 
Germination rate: defined according to Bartlett (1937).

Germination rate $=\frac{a+(a+b)+(a+b+c)+\ldots \ldots \ldots+(a+b+c+m)}{a(a+b+c+\ldots \ldots \ldots \ldots \ldots+m)}$

Where $(a, b, c$, and $m$ ) number of seedlings emerged at the first count, second count and final count and (n) it is the number of counts. Mean germination time and seedling vigor index: according to the recommendation outlined by Alvarado and Bradford (1987) and Ruan and Tylkowska (2002).These include the following:

$$
\text { Mean germination time }=\frac{\left(N_{1} \times T_{1}\right)+\left(N_{2} \times T_{2}\right)+\left(N_{3} \times T_{3}\right)+\left(N_{4} \times T_{4}\right)}{N_{1}+N_{2}+N_{3}+N_{4}}
$$
respectively.

$N_{1}, N_{2}, N_{3}$ and $N_{4}=$ First, Second, Third and Four Counts, respectively.

$T_{1}, T_{2}, T_{3}$ and $T_{4}=$ Time of First, Second, Third and Four Counts,

S. D. W = Seedling dry weight.

G. P. = Germination percentage.

At the final count, ten normal seedlings from each replicate were randomly taken randomly to measure plumule and radical length in $(\mathrm{mm})$, after then, the seedlings were dried in hot-air oven at $70{ }^{\circ} \mathrm{C}$ for 42 hours to obtain the seedling dry weight (g) according to Krishnasamy and Seshu (1990).

Accelerating Aging Test: was carried out according to ISTA rules (1999), where one hundred seeds each in four replicates are tied in a fine muslin cloth, then placed in a jar on a wire mesh. The lower part of the jar is filled with water. There were no direct contact between water in the jar and the seed in the muslin cloth. The jar was covered with the lid and sealed with paraffin wax to make it air tight. The jar was placed in an accelerated aging chamber maintain at $41 \pm 2 \mathrm{c}^{\circ}$ for 72 hours. After this period the seed package was removed and cooled in a desecrator. Then the seeds were subjected to normal germination test.

Electrical conductivity: was evaluated according to the procedures outlined by Matthews and Alison (1987).The HANNA conductivity meter ( $\mathrm{Hi}$ 80333) was used, where fifty seeds in three replications of tested samples were weighted to 2 decimal numbers and placed in $500 \mathrm{ml}$ flask and $250 \mathrm{ml}$ of distilled water was added. The flask was cover and placed in an incubator at a constant temperature of $20 \mathrm{c}^{\circ}$ for 24 hours after which the contents of the flask; were gently stirred. The electrical conductivity was measured in the solution after removing the seeds. The results were reported as $(\mu$ mhosig seeds).

\section{Electrical conductivity $=$ Reading of soaked seeds Weight of 50 seeds}


Collected data for each season were statistically analyzed by the technique of analysis of variance and the least significant differences (L.S.D.) of treatments (Gomez and Gomez, 1984). Bartlett test was done to the homogeneity of error variances. The test was significant for all traits except plant height, number of pod/ plant, seed weight/ plant, ungerminted seed percentage, electrical conductivity and seedling length was insignificant, thus the data of both years were combined for these traits only. Simple coefficients were calculated to compare the association between values of agronomic and seed technology characters.

\section{RESULTS AND DISCUCTION}

\section{Agronomic characters}

Data in Table 2 show that significant differences among faba bean genotypes for all studied characters except plant height characters was insignificant effects in both seasons. Genotypes 1,2,3 and 10 recorded the highest means of branches number/plant in the first and second seasons, respectively. Genotypes 9,2 and 7 were the earliest in flowering dates recording averages of 47 to 49 days in the first and second seasons respectively, on the other hand, genotypes 1,8 and 10 were the latest in flowering dates recording average (51-53) and (51-55) days in both seasons, respectively. Regarding maturity date genotype 9 was the earliest (153 days) in the first and second season, while, genotypes 5 and 6 were the latest with

Table (2): Means of some agronomic attributes of faba bean promising genotypes evaluated in 2011/2012 and 2012/2013 seasons.

\begin{tabular}{|c|c|c|c|c|c|c|c|}
\hline \multirow[b]{2}{*}{ Genotypes } & \multirow{2}{*}{\begin{tabular}{|c|} 
Plant \\
height $(\mathrm{cm})$ \\
$\begin{array}{c}\text { Compound } \\
\text { data }\end{array}$ \\
\end{tabular}} & \multicolumn{2}{|c|}{$\begin{array}{c}\text { Number of } \\
\text { tillers }\end{array}$} & \multicolumn{2}{|c|}{ Flowering date } & \multicolumn{2}{|c|}{ Maturity date } \\
\hline & & $\begin{array}{l}2011 / \\
2012\end{array}$ & $\begin{array}{l}2012 / \\
2013\end{array}$ & $\begin{array}{l}2011 / \\
2012\end{array}$ & $\begin{array}{l}2012 / \\
2013\end{array}$ & $\begin{array}{l}2011 / \\
2012\end{array}$ & $\begin{array}{l}2012 / \\
2013\end{array}$ \\
\hline G. 1 & \begin{tabular}{|l|}
99.7 \\
\end{tabular} & 5 & 6 & 51 & 53 & 158 & 156 \\
\hline G. 2 & 97.3 & 6 & 6 & 48 & 47 & 157 & 157 \\
\hline G. 3 & 96.7 & 5 & 6 & 50 & 52 & 158 & 154 \\
\hline G. 4 & 102.5 & 4 & 4 & 50 & 51 & 157 & 157 \\
\hline G. 5 & 98.0 & 5 & 5 & 51 & 50 & 157 & 159 \\
\hline G. 6 & 103.2 & 4 & 5 & 50 & 52 & 157 & 159 \\
\hline G. 7 & 102.5 & 5 & 4 & 49 & 48 & 154 & 156 \\
\hline G. 8 & 102.2 & 5 & 2 & 51 & 55 & 157 & 155 \\
\hline G. 9 & 97.2 & 5 & 4 & 47 & 49 & 153 & 153 \\
\hline G. 10 & 94.2 & 5 & 5 & 53 & 51 & 154 & 154 \\
\hline Giza 843 & 97.3 & 5 & 3 & 51 & 53 & 156 & 153 \\
\hline Misr 1 & 96.2 & 3 & 3 & 49 & 51 & 156 & 153 \\
\hline Improved G. 3 & 101.8 & 3 & 2 & 53 & 54 & 157 & 156 \\
\hline L. S. D. at $5 \%$ & NS & 2.0 & 1.0 & 2.0 & 2.0 & 2.0 & 2.0 \\
\hline \multicolumn{8}{|c|}{$\begin{array}{lll}\text { G.1 = Giza461 x Nubaria1 } & \text { G.2= Treble weight x Nubaria1 } & \text { G.3= Giza716 x Giza402 } \\
\text { G.4= Giza416 x Giza402 } & \text { G.5= Nubaria1 x Giza2 } & \text { G.6= Giza429 x Giza2 } \\
\text { G.7= Giza429 x Giza40 } & \text { G.8= Hybred8 x Giza461 } & \text { G.9= Hybred10 x Giza461 } \\
\text { G.10= (Treble weight x Giza461) x Misr1 } & \end{array}$} \\
\hline
\end{tabular}


average (159 days) in both season, respectively compared with the other genotypes. These results are in agreement with these obtained by Hossam (2010), he recorded that Giza Blanca cultivar gave valuable moral for all the studied traits i. e. number of branches/ plant and flower set, while, ILB 450 genotype gave the highest values for plant height. Also, Alghamdi, (2007), demonstrated that genotype Giza 402 showed the tallest plants.

Data in Table 3, cleared that significant differences among faba bean genotypes for all studied characters. Genotype 8 continue to surpass other studied genotypes in number of pod/plant (28 pod) followed by genotypes 5,1,3 and 9 compared with local cultivars. Genotypes 1 and 8 produced the highest averages of number of seed/plant (69 and 75) and (77 and 83) with significant differences among them in the first and second seasons, respectively. Regarding 100-seed weight, genotype 1 had the heaviest weight of 100 seed weight $(87.5 \mathrm{gm})$ followed by genotypes 4,6 and 2 (85.0, 81.5 and $80.8 \mathrm{gm}$ ) in the first season, whereas, genotypes 8 and 1 had the heaviest weight of 100 seed weight ( 61.3 and $61.2 \mathrm{gm}$ ) compared with the other genotypes in the second season. On the other hand, Genotypes 5 and 7 recorded the lowest weight of 100 seeds with average $(61.2$ and $56.6 \mathrm{gm})$ in both seasons, respectively. Genotypes 1 and 8 showed the highest seed weight/ plant (71.0 and 66.5), followed by genotype $4(65.4 \mathrm{gm})$ with no significant differences among them. All these genotypes are promising and could be recommended for releasing. Similar results were obtained by Hossam (2010), he reveled that Giza Blanca cultivar recorded valuable moral for all the studied traits i. e. (pod set, 100 seed weight and seed yield/ plant) except number of pods per plant, while, ILB 450 genotype gave the highest values for number of pod/ plant, which underscores the importance of the use of cultivar Giza Blanka and ILB 450 genotype in breeding programs to work on increasing the 100 seed weight as well as the individual yield plant. Haridy

Table (3): Means of some agronomic attributes of faba bean genotypes evaluated in 2011/2012 and 2012/2013 seasons.

\begin{tabular}{|l|c|c|c|c|c|c|}
\hline \multirow{2}{*}{ Genotypes } & $\begin{array}{c}\text { Number of } \\
\text { pod/plant }\end{array}$ & \multicolumn{2}{c|}{$\begin{array}{c}\text { Number of } \\
\text { seed/plant }\end{array}$} & $\begin{array}{c}\text { 100-sed weight } \\
\text { (gm) }\end{array}$ & $\begin{array}{c}\text { Seed } \\
\text { weight/plant } \\
\text { (gm) }\end{array}$ \\
\cline { 2 - 7 } & $\begin{array}{c}\text { Compound } \\
\text { data }\end{array}$ & $\begin{array}{c}\mathbf{2 0 1 1 /} \\
\mathbf{2 0 1 2}\end{array}$ & $\begin{array}{c}\mathbf{2 0 1 2 /} \\
\mathbf{2 0 1 3}\end{array}$ & $\begin{array}{c}\mathbf{2 0 1 1 /} \\
\mathbf{2 0 1 2}\end{array}$ & $\begin{array}{c}\mathbf{2 0 1 2} \\
\mathbf{2 0 1 3}\end{array}$ & Compound data \\
\hline G. 1 & 24 & 69 & 75 & 87.5 & 61.2 & 71.0 \\
\hline G. 2 & 23 & 59 & 67 & 80.8 & 50.2 & 61.1 \\
\hline G. 3 & 24 & 66 & 72 & 78.9 & 53.0 & 63.0 \\
\hline G. 4 & 22 & 59 & 65 & 85.0 & 52.4 & 65.4 \\
\hline G. 5 & 25 & 65 & 69 & 71.7 & 50.7 & 60.4 \\
\hline G. 6 & 20 & 48 & 52 & 81.5 & 41.5 & 60.0 \\
\hline G. 7 & 19 & 52 & 53 & 73.3 & 40.0 & 57.0 \\
\hline G. 8 & 28 & 77 & 83 & 76.6 & 61.3 & 66.5 \\
\hline G. 9 & 24 & 57 & 58 & 80.0 & 47.1 & 63.4 \\
\hline G. 10 & 21 & 57 & 57 & 72.7 & 42.5 & 58.2 \\
\hline Giza 843 & 21 & 62 & 56 & 74.3 & 43.0 & 61.4 \\
\hline Misr 1 & 23 & 66 & 65 & 73.9 & 48.1 & 61.2 \\
\hline Improved G. 3 & 21 & 62 & 58 & 77.3 & 45.4 & 63.4 \\
\hline L. S. D. at 5\% & 4.0 & 8.4 & 9.6 & 2.5 & 7.0 & 5.2 \\
\hline
\end{tabular}


and Amein, (2011), showed that Assiut 44 genotype was the best combiner for number of pods/plant and weight of dry seeds/plant. The genotype Assiut 39 genotype was the best combiner of number of seeds/pod.

\section{Seed technology characters}

High quality seed is an essential factor to ensure good crop establishment. The seed must be viable and possess physiological traits that allow rapid germination and seedling establishment. Seed germination and vigour are the main physiological quality attributes. The standard germination percentage, germination after aging and germination rate were significantly affected by studied genotypes faba bean as shown in (table 4). The acceptance level of germination percentage for certified faba bean seed should not be less than $85 \%$. All genotypes reached to the acceptance level of certified seed except genotypes number 2 and 5 were $82 \%$ and $80 \%$. Seed of genotypes 4,1,8 and 3 surpassed the other genotypes in germination percentage \% (96, 95, 94 and 93\%), respectively and it had minimum upnormal seedling $\%$ and ungerminated seed \% as compared to local varieties Giza 843, Misr 1 and Improved Giza 3. On the other hand, seed genotypes 2 and 5 gave the lowest percentage of normal seedlings (82 and $80 \%$ ) and highest percentage of upnormal seedlings \% and ungerminated seed \%. The highest averages of germination after aging (83, 83\%), (80, $82 \%)$ and $(80,81 \%)$ and germination rate $(0.818,0.793$ and 0.794$)$, respectively were obtained from seed genotypes number 4,1 and 8 as compared to local varieties Giza 843, Misr 1 and Improved Giza 3. The possible reason of lower germination after aging test might be that tolerance

Table (4): Means of Standard germination and seed vigour characters of faba bean genotypes evaluated in 2011/2012 and 2012/2013 seasons.

\begin{tabular}{|c|c|c|c|c|c|c|}
\hline \multirow[b]{3}{*}{ Genotypes } & \multicolumn{3}{|c|}{ Standard germination test } & \multirow{2}{*}{\multicolumn{2}{|c|}{$\begin{array}{c}\text { Germination after } \\
\text { aging (\%) }\end{array}$}} & \multirow[b]{2}{*}{$\begin{array}{c}\text { Germination } \\
\text { rate }\end{array}$} \\
\hline & $\begin{array}{c}\text { Germination } \\
(\%)\end{array}$ & $\begin{array}{c}\text { Abnormal } \\
\text { seedling } \\
(\%)\end{array}$ & $\begin{array}{l}\text { Ungerminatd } \\
\text { seed }(\%)\end{array}$ & & & \\
\hline & $\begin{array}{c}\text { Compound } \\
\text { data }\end{array}$ & $\begin{array}{c}\text { Compound } \\
\text { data }\end{array}$ & $\begin{array}{c}\text { Compound } \\
\text { data }\end{array}$ & $\begin{array}{l}2011 / \\
2012\end{array}$ & $\begin{array}{l}2012 / \\
2013\end{array}$ & $\begin{array}{c}\text { Compound } \\
\text { data }\end{array}$ \\
\hline G. 1 & 95 & 4 & 1 & 80 & 82 & 0.793 \\
\hline G. 2 & 82 & 11 & 7 & 68 & 70 & 0.722 \\
\hline G. 3 & 93 & 5 & 2 & 79 & 80 & 0.771 \\
\hline G. 4 & 96 & 2 & 2 & 83 & 83 & 0.818 \\
\hline G. 5 & 80 & 11 & 9 & 72 & 71 & 0.700 \\
\hline G. 6 & 87 & 10 & 3 & 70 & 75 & 0.749 \\
\hline G. 7 & 86 & 7 & 7 & 76 & 77 & 0.745 \\
\hline G. 8 & 94 & 4 & 2 & 80 & 81 & 0.794 \\
\hline G. 9 & 91 & 5 & 4 & 79 & 80 & 0.753 \\
\hline G. 10 & 90 & 7 & 3 & 78 & 78 & 0.744 \\
\hline Giza 843 & 88 & 9 & 3 & 73 & 73 & 0.713 \\
\hline Misr 1 & 90 & 7 & 3 & 78 & 79 & 0.743 \\
\hline Improved G. 3 & 88 & 8 & 4 & 75 & 74 & 0.719 \\
\hline L. S. D. at $5 \%$ & 3 & 2 & 2 & 3 & 5 & 0.032 \\
\hline
\end{tabular}


of subjected seed had declined in vigor leading to slower germination. These results are in agreement with Olasoji, et. al., (2011), they found that Laboratory germination percentages ranged from 52.00 to $86.67 \%(P<0.01)$ with overall means of $72.00 \%$. The highest germination percentages were found in cultivars NSWSS 4 and NSWSS 45 accessions with $86.57 \%$ meanwhile, the lowest germination percentages were found in cultivars NSWSS 50 and NSWSS 57 accessions with 52.00 and $58.67 \%$ germination respectively, and added there was a significant difference between faba bean genotypes on seed vigor traits as measured by (germination percentage after aging and germination rate), they reported that all the cultivars with the exception of NSWSS 56 recorded accelerated ageing germination percentage of less than $50 \%$ which is significantly lower than laboratory standard germination. Also, Ghassemi and Hosseinzadeh (2009) said that Zohreh faba bean cultivar had the highest germination rate compared with Aquodolce and Barakat cultivars.

Data in Table (5) show more details about seed and seedling vigor traits. These include seed vigor (mean germination time, electrical conductivity), seedling vigor (seedling length, seedling dry weight) and seedling vigor index. Seed genotypes 4,8 and 1 offers the lowest values of mean germination time $(4.8,5.1),(5.0,5.1)$ and $(5.0,5.2)$ day, respectively and lowest reading of electrical conductivity to soaked seeds $(13.1,14.6$ and $16.1 \mathrm{mmooh} / \mathrm{gm} / \mathrm{seed}$ ), respectively as compared to local varieties Giza 843, Misr 1 and Improved Giza 3. Genotypes of seed that show high levels of solute leakage are low vigor seeds and quality, this value could be as a result of hard seed coat that reduced seed exudates due to the impermeable nature of the coat. These results are in agreement with Ghassemi and Hosseinzadeh 2009) indicated that cultivar Barakat had the highest electrical conductivity compared with other cultivars, in contrast, cultivar Zohreh had the lowest solute leakage. Also Olasoji, et. al., (2011), showed that, significant differences in conductivity values among the accessions, the conductivity values ranged from 11.24 to $119.45 \mu \mathrm{Scm}^{-1} \mathrm{~g}^{-1}$ with overall mean of $62.24 \mu \mathrm{Scm}^{-1} \mathrm{~g}^{-1}$, cultivar NSWSS 50 recorded the lowest conductivity value of $11.24 \mu \mathrm{Scm}^{-1} \mathrm{~g}^{-1}$. Seedling vigor traits as nominated by seedling length, seedling dry weight and seedling vigor index also significantly differed among the studied genotypes. Genotypes 8 and 4 surpassed another genotypes in seedling length, while, genotype 4 ranked the first in seedling dry weight and seedling vigor index. Similar results were obtained by Olasoji, et. al., (2011), where they showed that, significant differences were observed for shoot length, seedling dry weight and seedling vigor index among all the genotypes, significant seedling vigor index was shown by cultivar NSWSS 4 due to its longer shoot length and seedling vigor index ranged from 1.16 to 2.58 with overall mean of 1.65 . 
Table (5): Means of some seed vigour and seedling characters of faba bean gnotypes evaluated in 2011/2012 and 2012/2013 seasons.

\begin{tabular}{|c|c|c|c|c|c|c|c|c|}
\hline \multirow[b]{2}{*}{ Genotypes } & \multicolumn{2}{|c|}{$\begin{array}{c}\text { Mean } \\
\text { germination } \\
\text { time } \\
\text { (day) }\end{array}$} & \multirow{2}{*}{\begin{tabular}{|c|}
$\begin{array}{c}\text { Electrical } \\
\text { conductivity } \\
\text { (mmooh/gm } \\
\text { / seed) }\end{array}$ \\
$\begin{array}{c}\text { Compound } \\
\text { data }\end{array}$
\end{tabular}} & \multirow{2}{*}{ 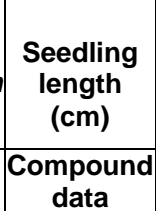 } & \multicolumn{2}{|c|}{$\begin{array}{l}\text { Seedling } \\
\text { dry weight } \\
\text { (gm) }\end{array}$} & \multicolumn{2}{|c|}{$\begin{array}{l}\text { Seedling } \\
\text { vigor index }\end{array}$} \\
\hline & $\begin{array}{l}2011 / \\
2012 \\
\end{array}$ & $\begin{array}{l}2012 / \\
2013\end{array}$ & & & $\begin{array}{l}2011 / \\
2012 \\
\end{array}$ & $\begin{array}{c}2012 / \\
2013 \\
\end{array}$ & $\begin{array}{c}2011 / \\
2012\end{array}$ & $\begin{array}{c}2012 / \\
2013\end{array}$ \\
\hline G. 1 & 5.0 & 5.2 & 16.1 & 25.3 & 10.3 & 8.5 & 984.3 & 792.5 \\
\hline G. 2 & 5.4 & 5.6 & 22.0 & 19.1 & 8.6 & 7.7 & 699.4 & 638.4 \\
\hline G. 3 & 5.1 & 5.2 & 16.7 & 24.0 & 10.0 & 8.6 & 929.6 & 789.3 \\
\hline G. 4 & 4.8 & 5.1 & 13.1 & 26.7 & 10.5 & 9.5 & 1009.5 & 897.7 \\
\hline G. 5 & 5.3 & 5.3 & 22.0 & 19.0 & 8.4 & 7.8 & 674.7 & 632.8 \\
\hline G. 6 & 5.2 & 5.3 & 19.8 & 22.3 & 9.1 & 7.8 & 793.2 & 691.8 \\
\hline G. 7 & 5.2 & 5.3 & 18.8 & 22.8 & 9.2 & 7.9 & 794.0 & 685.1 \\
\hline G. 8 & 5.0 & 5.1 & 14.6 & 27.0 & 10.0 & 8.2 & 936.9 & 758.7 \\
\hline G. 9 & 5.2 & 5.2 & 17.3 & 22.2 & 9.6 & 8.0 & 872.1 & 708.8 \\
\hline G. 10 & 5.3 & 5.2 & 18.3 & 22.1 & 9.7 & 8.4 & 873.1 & 760.6 \\
\hline Giza 843 & 5.5 & 5.7 & 21.2 & 21.7 & 9.2 & 7.5 & 810.7 & 645.2 \\
\hline Misr 1 & 5.2 & 5.4 & 17.9 & 22.9 & 9.6 & 7.7 & 867.9 & 691.7 \\
\hline Improved G. 3 & 5.6 & 5.6 & 21.4 & 21.1 & 9.3 & 7.5 & 821.5 & 654.9 \\
\hline L. S. D. at $5 \%$ & 0.22 & 0.43 & 0.67 & 1.39 & 0.82 & 0.57 & 86.0 & 58.7 \\
\hline
\end{tabular}

Relationships among studied characters:

The correlation coefficient for the relationships between the studied traits listed in Table 6. There were positively and highly significant correlations between number of seed weight/plant and each of number of seed/plant $(r=0.912)$, germination percentage $(r=0.560)$, seedling length $(r=0.567)$, seedling vigor index $(r=0.526)$ and germination rate $(r=0.584)$ and highly significant negatively correlations between seed weight/plant and electrical conductivity $(\mathrm{r}=-0.556)$ and mean germination time $(-0.531)$. Also positively and highly significant correlations between germination percentage and each of germination after seed aging ( $r=0.909)$, seedling length ( $r=0.912)$, seedling vigor index $(r=0.958)$, germination rate $(r=0.877)$ and seedling dry weight $(r=0.885)$ and highly significant negatively correlations between germination percentage and mean germination time $(r=-0.647)$ and electrical conductivity $(r=-0.897)$. Also positively and highly significant correlations between 100-seed weigh and each of germination percentage (0.516), seedling vigor index (0.531), germination rate (0.539) and seedling dry weight $(0.535)$. This results agreed with those reported by Alghamdi, 2007, he found that significant positive correlations were detected between seed yield (tha) and each of number of pods per plant, number of seeds per plant and seed weight per plant, while, negative and significant correlations were observed between seed yield (tha) and each of flowering time, maturity date, number of branches per plant and 100seed weight. Furthermore, these results are in agreement with Makkawi, et. al., (1999), they recorded that standard germination showed significant negative correlation with electrical conductivity and significant negative correlation between electrical conductivity and 100 seed weight. They added that shoot length negatively with 100 seed weight, seedling dry weight and electrical conductivity. The electrical conductivity was negatively correlated with seedling weight. 
EI-Emam, A. A. M. and E. M. Rabie

6- 
In conclusion, Evaluation and selection faba bean genotypes for agronomic and seed technology characters are important to get the same high seed yield and high seed quality cultivars. Accordingly, accumulated data of agronomic and seed quality characteristics that faba bean genotypes number 4,1,8 and 3 (G 461xGiza 402, Giza 461xNubaria 1, Hybrid 8xGiza 461 and Giza 718xGiza 402) combined high seed yield and yield components as well as good seed quality compared with the three local commercial cultivars, which underscores the importance of registration of these genotypes commercial varieties and using them in breeding programs to work on increasing the 100 seed weight and the individual yield plant as well as high seed quality and could be recommended for release to be grown in North Egypt.

\section{REFERENCES}

Alghamdi, S.S. (2007). Genetic behavior of some selected faba bean genotypes. African Crop Scie., Conference Proceedings 8: 709-714.

Alvarado, A.D. and K.J. Bradford (1987). Priming and storage of tomato (Lycopersicum esculentum) seeds. I. Effect of storage temperature on germination rate and viability. Seed science and technology, 16: 601-612.

Bartlett, M. S. (1937). Some samples of statistical method of research in agriculture and applied biology. Jour. Roy. Soc, 4:2.

Cecilia, B., P. Silva, J. Auza and E. Acevedo, (2013). Evaluation for fresh consumption of new broad bean genotypes with a determinate growth habit in central Chile. Chilean J. of Agric. Res., 73 (3): 225232.

EL-Emery, M. I. (1997). Evaluation of seed quality of selected faba bean (Vicia Faba I.) genotypes under irrigation and rainfed at nubaria region. Egypt. J. Appl. Sci., 12 (2): 103-115.

Erkut P., (2007). Relationships among electrical conductivity of seed leakage, germination, field emergence percentage and some seed traits in faba bean (Vicia faba L.). Asian J. of Chemistry, 19 (4): 3178-3184.

Ghassemi-G., K. and Hosseinzadeh M.A. (2009). Changes in seed vigour of faba bean (Vicia faba L.) cultivars during development and maturity. ), Seed Sci. and Technol., 37: 713-720.

Gomez, K. A. and A. A. Gomez (1984). Statistical Procedures for Agricultural Research. $2^{\text {nd }}$ Ed. John Whiley and Sons.

Hampton, J. G. and P. Coolbear, (1990). Potential versus actual seed performance - Can vigour testing provide an answer? seed scie. and Tecno., 18: 215-228.

Haridy, A.G.H and K.A. Amein. (2011). The inheritance of some agronomical traits, protein content and seed beetle (Callosobrucus maculates Fab.) Infestation in Faba Bean (Vicia Faba L.). Australian J. of Basic and Applied Sciences, 5(6): 1215-1222.

Hossam M.I., (2010). Heterosis, combining ability and components variance in faba bean (Vicia Faba L.). Arid Land Agric. Sci., 21 (1): 35-50. 
Huber, R.; E.R. Keller and F. Schwendimann (1987). Effects of biological nitrogen fixation by faba beans (Vicia Fab L.) on the nitrogen economy of the soil. Fabis News, 1 (17): 14-20.

I.S.T.A. (1985). International Rules for Seed Testing. Seed Science and Technol., (13): 307-355.

I.S.T.A. (1999). International Rules for Seed Testing, Handbook of Vigor Test Methods. $3^{\text {rd }}$ Edition: 22-35.

Krishnasamy, V. and D.V. Seshu (1990). Phosphine fumigation influence on rice seed germination and vigor. Crop Sci., 30: 28- 85.

Krystyna K.; Jerzy S. and S. Dul (2000). Relationship between laboratory seed quality tests and field emergence of common bean seed. Crop Science, 40 (2): 470-475.

Makkawi, M.; M. El Balla; Z. Bishaw and A. I. G. Van Gastel, 1999. The relationship between seed vigour tests and field emergence in lentil (Lens culinaris Medikus). Seed Sei. and Technol., 27: 657-668.

Matthews, S. and A. P. Alison (1987). Electrical Conductivity Test. Handbook of Vigor Test Methods, $2^{\text {nd }}$ ed., 37-43. Published by ISTA. Seed Scie. \& Technol., (27): 771-778.

Olasoji, J. O.; S. R. Akande and O. F. Owolade (2011). Genetic variability in seed quality of African yam beans (Sphenostylis stenocarpa Hochst. Ex A. Rich Harms). African J. of Agricultural Research. 6(27): 58485853.

Redden, R; Zong X; van J. Leur; S. Wang; S. Bao; J. Paull; T. Leonforte; L. Yujiao and R. Ford (2007). Increased productivity of cool season pulses in rain-fed agricultural systems of China and Australia. Final Report ACIAR Project: CS1/2000/035.

Ruan, S.; Q. Xue and K. Tylkowska (2002). Influence of priming on germination of rice (Oryza sativa L.) seed and seedling emergence and performance in flooded soil. Seed Scie. and Technol., 30: 61-67.

Torres, A.M.; C.M. Avila; N. Gutierrez; C. Palamino; M.T. Moreno and J.I. Cubero (2010). Marker-assisted selection in faba bean (Vicia faba L.). Field Crops Research, 115: 243-252.

Wally, E. A.; M. A. Farghally; H. S. Abbas and Dina S. Moselhy (2010). Performance of several newly faba bean lines under Assiut conditions. Minia J. of Agric. Res. \& Develop. 30 (3): 443-456.

Younis, S. A.; F. I. Al-Rawi and E. G. Hagop (1990). Physiological and biochemical parameters of seed quality in some rice varieties (Oryza Sativa L.)., Seed Research, 18: 148-153. 
تقييم صفات المحصول و صفات جودة التقاوي لبعض سلالات الفول البلدى المبشرة

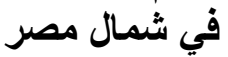
أحمد عبد اللطيف محمد الامام و السيد محمد ربيع

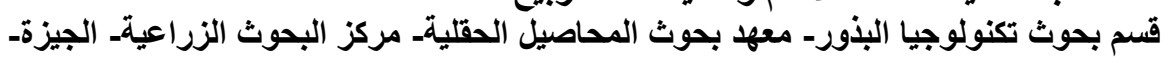

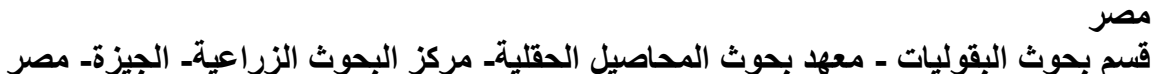

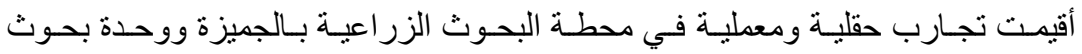

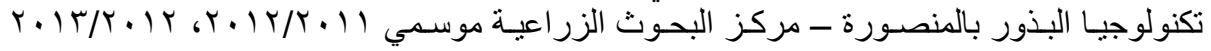

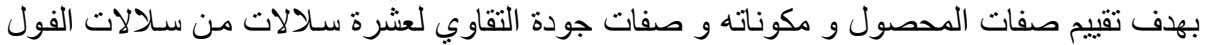

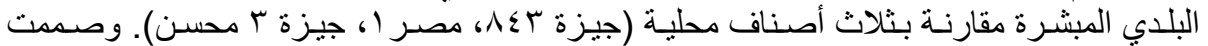
التجربة في قطاعات كاملة العشو ائية في ثلاث التاث مكررات.

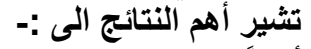

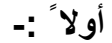

اختلفت السلالات معنويا فيما بينها في صفات المحصول ومكوناته حيث كانت السلالة رقم

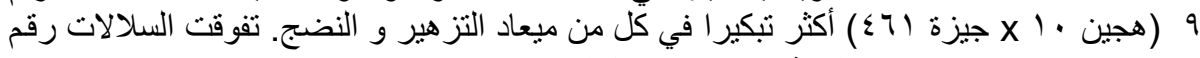

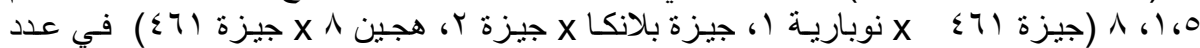

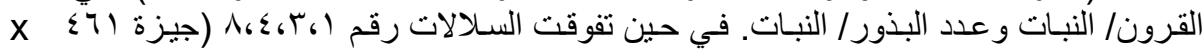

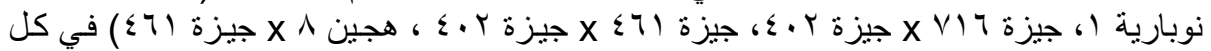

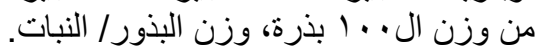
ثانيا :-

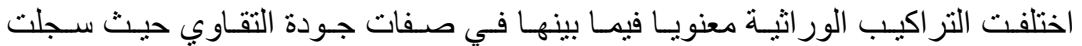

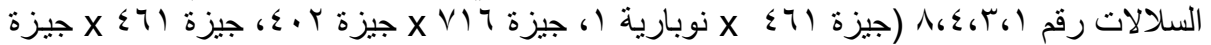

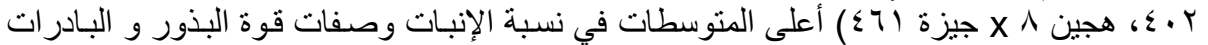
مقارنة بالأصناف التجارية المحلية.

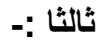

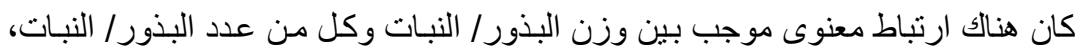

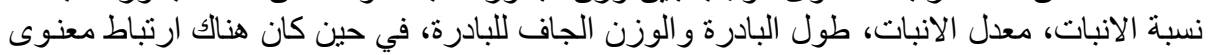

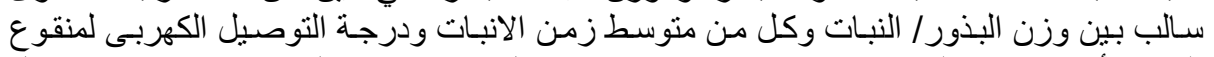

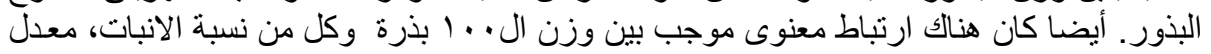

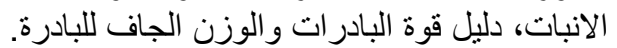

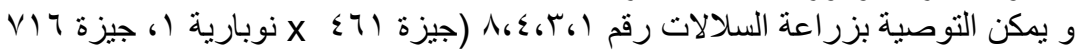

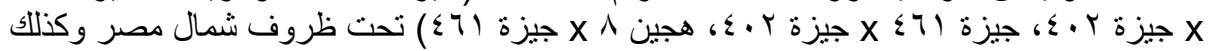

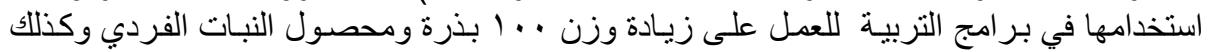
جودة البذور العالية. 